\title{
Wild mammal dung abundance in Lake Mburo National Park is lower than in adjacent ranchlands
}

\author{
Antonia Nyamukuru \\ I College of Agricultural and Environmental Sciences, Makerere University, P.O. Box 7062, Kampala, Uganda \\ Corresponding author: Antonia Nyamukuru (nyamukuru@gmail.com)
}

Academic editor: S. Williams | Received 28 April 2019 | Accepted 29 November 2019 | Published 11 December 2019

http://zoobank.org/0708D586-CBF7-46C9-B456-10E03BAD56A5

Citation: Nyamukuru A (2019) Wild mammal dung abundance in Lake Mburo National Park is lower than in adjacent ranchlands. Nature Conservation 37: 123-131. https://doi.org/10.3897/natureconservation.37.35814

\begin{abstract}
The establishment of livestock ranchlands adjacent to protected areas in savanna ecosystems is believed to threaten wild animals. Intensive competition for vegetative resources, water and poaching are considered to be immediate factors that reduce the capacity of protected areas to sustain wild mammals. The coexistence of wild mammals and ranchlands is common in Southern Africa but has rarely been suggested as a viable conservation option in East Africa. To assess the importance of ranchlands in conserving wild mammals, 36 plots of $20 \times 20 \mathrm{~m}$ dimension were positioned along a $7240 \mathrm{~m}$ stretch from the boundary in Lake Mburo National Park (LMNP) and 36 plots of similar dimension were set within the ranchlands adjacent to the Park. The dung counts of different species recorded in the plots were used as a relative index of mammal abundance in the ranchlands and in LMNP. The results reveal 18 wild mammal species recorded in both sampled areas, 12 within LMNP and 17 in the adjacent ranchlands. The topi Damaliscus lunatus was only found in the park. Total dung count estimated in both ranchlands and LMNP was 2,586 with LMNP accounting for $29 \%$ and ranchlands $71 \%$. In terms of wild mammal dung, ranchlands had a higher wild mammal dung count than LMNP (30\% higher). The study points to the compatibility of the two land uses in conserving wild mammals and biodiversity in general, negating the common belief of competition and exclusion. Future research is needed on the compatibility of ranchlands with protected areas on biodiversity status of other species.
\end{abstract}

\section{Keywords}

abundance, cattle, land use, livestock, protected area, ranches, savanna, Uganda, wild mammals

Copyright Antonia Nyamukuru. This is an open access article distributed under the terms of the Creative Commons Attribution License (CC BY 4.0), which permits unrestricted use, distribution, and reproduction in any medium, provided the original author and source are credited. 


\section{Introduction}

The assumption that biodiversity is higher in protected areas than in other land uses has dominated biodiversity conservation discourse (Stoner et al. 2007; Geldmann et al. 2013; UNEP-WCMC et al. 2018). This assumption is further supported by the fact that land use is among the major threats to biodiversity (Sala et al. 2000; Asner et al. 2010). To conservation purists, the exclusion of land uses that are perceived to be incompatible with protected areas is the best way to counter biodiversity loss. Unfortunately, exclusion has not completely halted the loss of biodiversity in protected areas and in some cases has exacerbated human-wildlife conflict since communities still want to access essential resources within the protected areas (Mistry and Beradi 2000; Lindsey et al. 2012). The demand for land and its resources in areas adjacent to protected areas managed for biodiversity conservation is increasingly putting pressure on biodiversity conservation areas, prompting the need for land use options that can simultaneously conserve biodiversity and serve other production uses (Prins 1992; Marchant 2010). Such land uses act as dispersal areas for wild animals especially where the land tenure system does not restrict access to environmental resources (Okello and Kioko 2010).

Lake Mburo National Park (LMNP), the smallest grassland protected area $\left(260 \mathrm{~km}^{2}\right)$ in Uganda located within a dryland savanna, is surrounded by livestock ranchlands (Blösch 2002). The land tenure systems in Lake Mburo include private property, non-property, customary communal and customary individualized tenure (Kisamba-Mugerwa et al. 2006). The creation of the park resulted in local resistance and ensuing socio-political conflicts (Marquardt et al. 1994). Grazing land was reduced and livestock restricted from entering the gazetted park area since grazing was perceived to be incompatible with wildlife conservation. However, the decision to exclude livestock grazing from the park was not guided by any critical study to assess whether exclusion was the best option for conserving biodiversity. Using dung counts of wild mammals in LMNP and the adjacent ranchlands, this study assesses the compatibility of the two intensive land uses in conserving wild mammals. The aim of this study is to test the common assumption that biodiversity is higher in protected areas than on other land uses.

\section{Methods}

The study was conducted in the eastern part of LNMP and the adjacent ranchlands, in Kiruhura District, South Western Uganda. The park lies at an altitude of about 1200 $\mathrm{m}$ above sea level, average annual rainfall of $888 \mathrm{~mm}$ and mean annual temperatures of $22.9^{\circ} \mathrm{C}$ are recorded at the nearest weather station in Mbarara (Blösch 2002). The park is part of the Kagera savanna ecosystem (Blösch 2002). The original vegetation is classified as dry Vachellia Savanna with Vachellia species being dominant (Langdale-Brown et al. 1964) though currently savanna vegetation is heavily degraded leaving a woody layer of Acacia hockii (Blösch 2002). Mammalian wildlife currently inhabiting the park 
include zebra Equus quagga boehmi, impala Aepyceros melampus, waterbuck Kobus ellipsiprymnus, eland Taurotragus oryx, topi Damaliscus lunatus, warthog Phacochoerus africanus and bushbuck Tragelaphus scriptus. The Ankole cattle Bos taurus and goats Capra hircus are the common livestock (Blösch 2002; Rannestad et al. 2006). LMNP is largely used for wildlife conservation and recreation/ tourism. Outside the park, ranchland and communal grazing lands are the major land use types (Kagoro-Rugunda 2004; Rannestad et al. 2006).

I systematically paired sites in LMNP and the adjacent ranchlands running parallel to the boundary across the two land uses between June and September 2015. The boundary between LMNP and the ranchlands is unfenced and demarcated with concrete pillars. The herbaceous vegetation on either side of the boundary is different but the woody vegetation is similar (Nyamukuru et al. 2019). Additionally, the herbaceous composition is associated with mammals and the grazing intensity is different between the ranchlands and LMNP (Nyamukuru et al. 2019; Nyamukuru et al. unpublished data). In total, four sites of $1060 \mathrm{~m}$ each in LMNP and in the ranchlands were paired (Figure 1). In each site, I established 9 plots of $20 \times 20 \mathrm{~m}$, giving a total of 72 plots. The plots were positioned at progressive distances of 300, 420 and $540 \mathrm{~m}$ away from the boundary into LMNP and the same distances were applied from the borders into the ranchlands. The distance of $300 \mathrm{~m}$ away from the boundary was applied to avoid the edge effect (Broadbent et al. 2008). Furthermore, wild animals maintain a shorter distance away from grazing (livestock) than from other human activities like agriculture and settlement (Okello and Kioko 2010). I recorded mammals by looking at the presence and frequency of dung piles in $20 \times 20 \mathrm{~m}$ plot. The chances of finding dung piles were equally likely on both sides of the boundary. The dung pile was identified and attached to mammal species with the help of an experienced game ranger. The dung counts in this study are used as a proxy for biodiversity, distribution and relative abundance of mammals. The assumption is that if dung count rates are higher in the ranchlands than the national park, this may suggest that the population density could be higher in the ranchlands that produce it. The dung counts were used over alternative methodologies because studies have shown that they are accurate estimates of mammal population biomass and density (Barnes 2001; Young et al. 2005; Boafo et al. 2009). Secondly, the dung method was used in this study because I assumed that a short distance of $540 \mathrm{~m}$ away from the boundary will capture animals with both large home range and those that range near the boundary. Although the distance seems small, from the data, that error does not affect the results and the conclusion. The use of dung to estimate mammal densities and biomass has also been demonstrated by several researchers (Karanth and Sunquist 1992; Plumptre and Harris 1995; Young et al. 2005). To test whether the relative abundance of wild mammals is greater inside LMNP than the adjacent ranchlands, a generalized linear mixed effect model with a restricted maximum likelihood (nlme R package) was used. The dung count in the model was used as a response variable and land use as a predictor variable. Random factors were mammal species identity and plot. The distance from the boundary was added to the model after testing the effect of land use to test if it could explain additional differences. The analysis was performed using R statistical software (R Development Core Team 2016). 


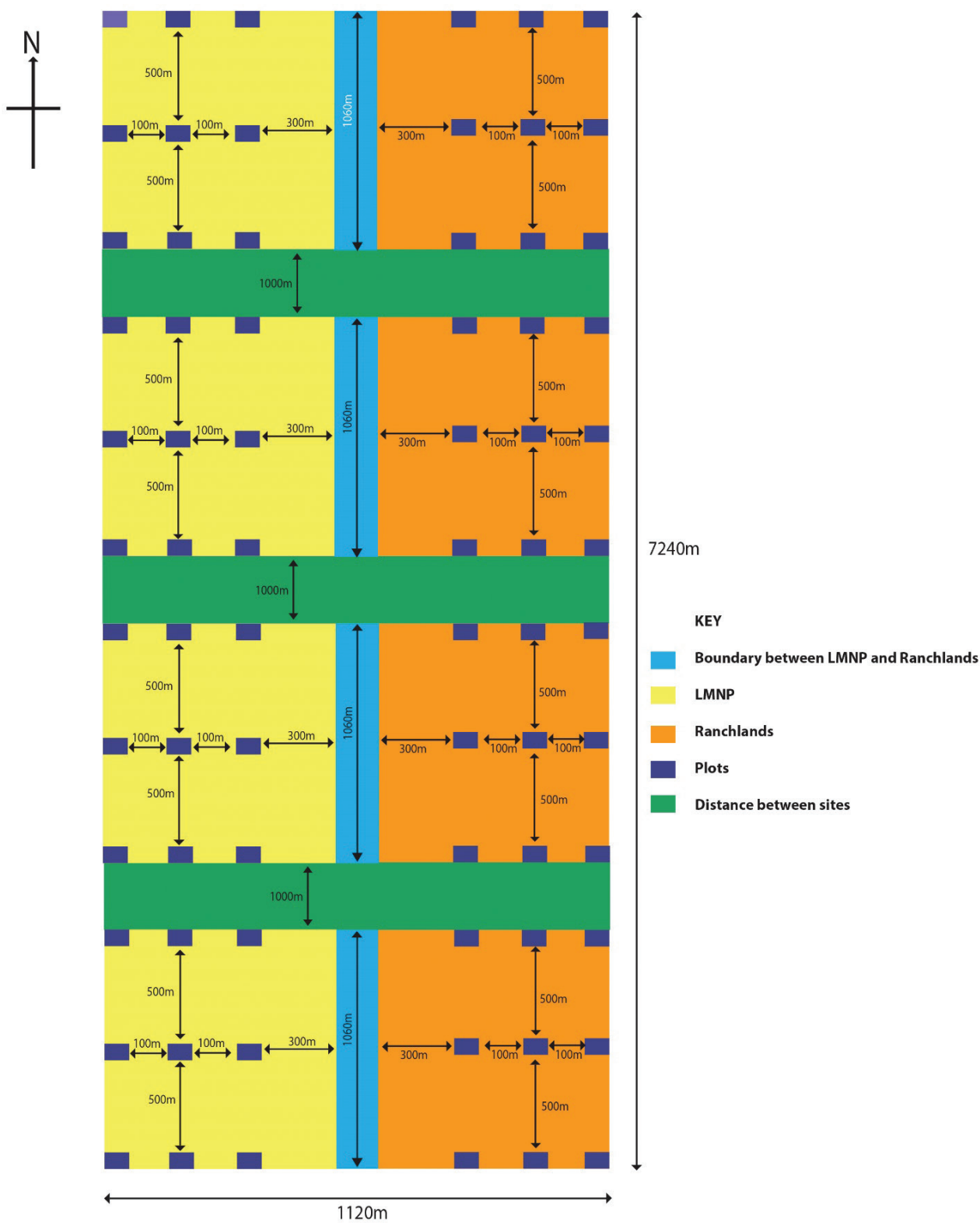

Figure I. The sampling design within Lake Mburo National Park and ranchlands. Eight sites (4 in LMNP and 4 in ranchlands) were sampled out; in each site 9 plots of $20 \times 20 \mathrm{~m}$ were designated.

\section{Results and discussion}

Results from the study reveal the presence and distribution of wild mammals within the two land uses. In total, 18 wild mammals were found to range within the sampled corridor, with ranchlands recording more (17) wild mammal species than LMNP (Table 1). There is a significant difference in dung counts between LMNP and the ranchlands 
(estimate $=0.55$, standard error $=0.17, z$ value $=3.21, p<0.01)$. Ranchlands still held a higher wild mammal dung count $(1,183)$ as compared to LMNP $(629)$ suggesting that the population density could be higher in the ranchlands, and that they are a preferred site for wild mammals. The distance from the boundary did not explain any additional variations (estimate $=-0.00$, standard error $<0.01, z$ value $=-1.61, p=0.11$ ) implying that land use or a different factor influences the relative abundance of wild mammals. The likely factor is the variation of the herbaceous vegetation in the two land uses $(\mathrm{Ny}$ amukuru et al. 2019) which could suggest different diet in the ranchlands and LMNP. Studies further reveal the presence of cattle Bos taurus and horses Equus caballus within LMNP but no goats Capra hircus (Table 1). The distribution of individual species within the two land uses based on study results shows a coexistence of livestock and wild mammals. Zebra Equus quagga boehmi, cattle Bos taurus and eland Taurotragus oryx had a higher dung count in the ranchlands than LMNP, bushbuck Tragelaphus scriptus, bush duiker Sylvicapra grimmia, dwarf mongoose Helogale parvula and goat Capra hircus were only found in the ranchlands (Table 1 ).

Results of the survey indicate that contrary to received conventional wisdom (Geldmann et al. 2013) ranchlands returned a higher relative abundance of wild mammals than LMNP. This is evidence that wild mammals either periodically migrate from

Table I. The dung counts of wild mammals and livestock recorded in Lake Mburo National Park and the adjacent ranchlands.

\begin{tabular}{llcc}
\hline \multicolumn{1}{c}{ English name } & \multicolumn{1}{c}{ Zoological name } & Lake Mburo National Park & Ranchlands \\
\cline { 3 - 4 } & & \multicolumn{2}{c}{ Dung counts } \\
Wild mammals & & 266 & 538 \\
Zebra & Equus quagga boehmi & 163 & 6 \\
Buffalo & Syncerus caffer & 68 & 28 \\
Warthog & Phacochoerus africanus & 66 & 466 \\
Impala & Aepyceros melampus & 31 & 82 \\
Eland & Taurotragus oryx & 12 & 9 \\
Baboon & Papio anubis & 8 & - \\
Topi & Damaliscus lunatus & 6 & 10 \\
Waterbuck & Kobus ellipsiprymnus & 5 & 3 \\
Hippopotamus & Hippopotamus amphibius & 2 & 2 \\
Bush pig & Potamochoerus larvatus & 1 & 7 \\
African hare & Lepus victoriae & - & 3 \\
Bushbuck & Tragelaphus scriptus & - & 12 \\
Bush duiker & Sylvicapra grimmia & 1 & 3 \\
Monkey & Cercopithecus aethiops & - & 6 \\
Hare & Lepus spp & - & 4 \\
Mongoose & Helogale spp. & - & 2 \\
Dwarf mongoose & Helogale parvula & - & 2 \\
Hyaena & Crocuta crocuta & 629 & 1,183 \\
Total & & & \\
Livestock & & 122 & 619 \\
Ankole cattle & Bos taurus & 1 & 23 \\
Horse & Equus caballus & - & 9 \\
Goat & Capra hircus & 123 & \\
Total & & & \\
\hline
\end{tabular}


the Park to neighboring land uses or live there as residents as also observed by Guard (1991) and Averbeck (2002) in Lake Mburo ecosystem. The presence of bushbuck Tragelaphus scriptus, hyaena Crocuta crocuta, mongoose Helogale spp., hare Lepus species and bush duiker Sylvicapra grimmia on ranchlands and not LMNP further demonstrates the lack of imminent threats to these animals on the ranchlands but rather a possibility of coexistence. By choosing to range on ranchlands rather than the protected area, these species affirm the existence of more suitable ecological conditions and the differences in habitat selection by different species. A similar study by Okello and Kioko 2010 found that the likelihood of finding several species in Olgulului - Ololorashi Group Ranch was high compared to Amboseli National Park due to the different ecological needs of species. The existence of cattle Bos taurus in the park, and not goats Capra hircus, also points to greater and deeper functional relationships between specific species and rangelands. These results are also supported by Rannestad et al. (2006) who undertook similar studies in Lake Mburo using a different approach of line transect distance sampling method in the same study sites but at a wider scale.

The coexistence of wild mammals and livestock in rangelands as demonstrated by studies conducted in such lands (Jensen 2001; Niamir-Fuller et al. 2012), has tended to overshadow the conflict narrative. Local communities have, amidst challenges, sustained their different livelihoods in such environments. The Lake Mburo scenario is an example; before gazetting and demarcating the park in 1983, pastoralists coexisted with wildlife for a long time dating back to the 1800s when the ecosystem was a traditional grazing land and hunting ground for the King (Marquardt et al. 1994). However, against that, Caro et al. (1998) and Crosmary et al. (2015) reported higher wild mammal densities in the protected area than the adjacent land uses. Furthermore, the presence of wild mammals in ranchlands means that these land uses are dispersal areas of LMNP and hence relieving the wild mammal population density pressure from the small park.

\section{Conclusions}

Notwithstanding studies that suggest greater competition and conflict between wildlife and other land uses (Prins 2000; Young et al. 2005; Niamir-Fuller et al. 2012), results from this study tend to demonstrate the positive conservation value of ranchlands in the conservation of biodiversity, specifically wild mammals. However, given the delicate nature of wildlife-human interface, there is need for further research on the biodiversity status of other species in the ecosystem to reach a conclusive and informed decision on the compatibility of the two land use types within the greater Lake Mburo ecosystem and its conservation goals. Given the existence of wild mammals in ranchlands and livestock in LMNP as demonstrated in this study, it is important that LMNP and nearby land owners reach agreed management positions. The two parties ought to come up with strategic action on resolving compensation and injury claims raised by ranchers as well as livestock that stray into the LMNP. 


\section{Acknowledgements}

I thank the ranchers and Uganda Wildlife Authority for granting me permission to access the ranchlands and LMNP. Fred Matovu supported in data collection. Norwegian Programme for Capacity Building in Higher Education and Research for Development (NORHED) under the NORAD programme funded this research (UGA-13/0019). I am grateful for useful comments from anonymous reviewers.

\section{References}

Asner GP, Loarie SR, Heyder U (2010) Combined effects of climate and land-use change on the future of humid tropical forests. Conservation Letters 3(6): 395-403. https://doi. org/10.1111/j.1755-263X.2010.00133.x

Averbeck C (2002) Population Ecology of Impala (Aepyceros melampus) and CommunityBased Wildlife Conservation in Uganda. PhD Thesis, Technische Universität München.

Barnes RF (2001) How reliable are dung counts for estimating elephant numbers? African Journal of Ecology 39(1): 1-9. https://doi.org/10.1111/j.1365-2028.2001.00266.x

Blösch U (2002) The Dynamics of Thicket Clumps in the Kagera Savanna Landscape, East Africa. PhD Thesis, Swiss Federal Institute of Technology, Zurich. https://doi.org/10.3929/ ethz-a-004321555

Boafo Y, Manford M, Barnes RF, Hema EM, Danquah E, Nandjui A, Dubiure UF (2009) Comparison of two dung count methods for estimating elephant numbers at Kakum Conservation Area in southern Ghana. Pachyderm 45: 34-40. https://doi. org/10.13140/2.1.1919.5525

Broadbent EN, Asner GP, Keller M, Knapp DE, Oliveira PJ, Silva JN (2008) Forest fragmentation and edge effects from deforestation and selective logging in the Brazilian Amazon. Biological Conservation 141(7): 1745-1757. https://doi.org/10.1016/j.biocon.2008.04.024

Caro TM, Pelkey N, Borner M, Campbell KLI, Woodworth BL, Farm BP, Kuwai J, Huish SA, Severre ELM (1998) Consequences of different forms of conservation for large mammals in Tanzania: Preliminary analyses. African Journal of Ecology 36(4): 303-320. https://doi. org/10.1046/j.1365-2028.1998.00147.x

Crosmary W-G, Chamaillé-Jammes S, Mtare G, Fritz H, Côté SD (2015) Decline of sable antelope in one of its key conservation areas: The greater Hwange ecosystem, Zimbabwe. African Journal of Ecology 53(2): 194-205. https://doi.org/10.1111/aje.12207

Geldmann J, Barnes M, Coad L, Craigie ID, Hockings M, Burgess ND (2013) 'Effectiveness of terrestrial protected areas in reducing habitat loss and population declines'. Biological Conservation 161: 230-238. https://doi.org/10.1016/j.biocon.2013.02.018

Guard M (1991) The interaction Between Domestic Animals and Wild Ungulates in Lake Mburo National Park, Uganda: A question of Competition or Complementarity. Msc Thesis, Makerere University. 
Jensen MN (2001) Can cows and conservation mix? Conservationists, ranchers, and scientists attempt to preserve biodiversity and the cowboy way of life. Bioscience 51(2): 85-90. https://doi.org/10.1641/0006-3568(2001)051[0085:CCACM]2.0.CO;2

Kagoro-Rugunda G (2004) Crop raiding around Lake Mburo National Park, Uganda. African Journal of Ecology 42(1): 32-41. https://doi.org/10.1111/j.0141-6707.2004.00444.x

Karanth KU, Sunquist ME (1992) Population structure, density and biomass of large herbivores in the tropical forests of Nagarohole, India. Journal of Tropical Ecology 8(1): 21-35. https://doi.org/10.1017/S0266467400006040

Kisamba-Mugerwa W, Pender J, Kato E (2006) Impacts of Individualization of Land Tenure on Livestock and Rangeland Management in Southwestern Uganda. Paper presented at the $11^{\text {th }}$ Biennial Conference of International Association for Study of Common Property, Bali.

Langdale-Brown I, Osmaston H, Wilson JG (1964) The Vegetation of Uganda and its Bearing on Land Use. Uganda Government Printer, Entebbe, 159 pp.

Lindsey PA, Masterson CL, Beck AL, Romañach S (2012) Ecological, Social and Financial Issues Related to Fencing as a Conservation Tool in Africa. Fencing for conservation. Springer, 215-234. https://doi.org/10.1007/978-1-4614-0902-1_12

Marchant R (2010) Understanding complexity in savannas: Climate, biodiversity and people. Current Opinion in Environmental Sustainability 2(1-2): 101-108. https://doi. org/10.1016/j.cosust.2010.03.001

Marquardt M, Infield M, Namara A (1994) Socio-Economic Survey of Communities in the Buffer Zone of Lake Mburo National Park. Makerere Institute of Social Research, Kampala and Land Tenure Centre.

Mistry J, Beradi A (2000) World Savannas. Routledge, London. https:/doi. org/10.4324/9781315839523

Niamir-Fuller M, Kerven C, Reid R, Milner-Gulland E (2012) Co-existence of wildlife and pastoralism on extensive rangelands: competition or compatibility? Pastoralism: Research. Policy \& Practice 2: 1-14. https://doi.org/10.1186/2041-7136-2-8

Nyamukuru A, Grytnes JA, Tabuti JRS, Totland Ø (2019) Unfenced Borders Cause Differences in Vegetation and Fauna Between Protected and Unprotected Areas in a Tropical Savanna. Tropical Conservation Science 12: 1-12. https://doi.org/10.1177/1940082919870371

Okello MM, Kioko JM (2010) Contraction of Wildlife Dispersal Area in Olgulului- Ololorashi Group Ranch Around Amboseli National Park, Kenya. The Open Conservation Biology Journal 4(1): 34-45. https://doi.org/10.2174/1874839201004010034

Plumptre AJ, Harris S (1995) Estimating the biomass of large mammalian herbivores in a tropical montane forest: A method of faecal counting that avoids assuming a 'steady state' system. Journal of Applied Ecology 32(1): 111-120. https://doi.org/10.2307/2404420

Prins HHT (1992) The pastoral road to extinction - competition between wildlife and traditional pastoralism in East Africa. Environmental Conservation 19(2): 117-123. https:// doi.org/10.1017/S0376892900030587

Prins HHT (2000) Competition Between Wildlife and Livestock in Africa. Wildlife Conservation by Sustainable Use. Kluwer Academic Publishers, Boston, 51- 80. https://doi. org/10.1007/978-94-011-4012-6_5 
Rannestad OT, Danielsen T, Moe SR, Stokke S (2006) Adjacent pastoral areas support higher densities of wild ungulates during the wet season than the Lake Mburo National Park in Uganda. Journal of Tropical Ecology 22(6): 675-683. https://doi.org/10.1017/ S0266467406003610

R Development Core Team (2016) R: A language and environment for statistical computing. $\mathrm{R}$ Foundation for Statistical Computing, Vienna.

Sala OE, Chapin FS, Armesto JJ, Berlow E, Bloomfield J, Dirzo R, Huber-Sanwald E, Huenneke LF, Jackson RB, Kinzig A (2000) Global biodiversity scenarios for the year 2100. Science 287(5459): 1770-1774. https://doi.org/10.1126/science.287.5459.1770

Stoner C, Caro T, Mduma S, Mlingwa C, Sabuni G, Borner M (2007) Assessment of effectiveness of protection strategies in Tanzania based on a decade of survey data for large herbivores. Conservation Biology 21(3): 635-646. https://doi.org/10.1111/j.15231739.2007.00705.x

UNEP-WCMC IUCN, NGS (2018) Protected Planet Report 2018. UNEP-WCMC, IUCN and NGS: Cambridge UK, Gland, Switzerland and Washington. www.unep-wcmc.org

Young TP, Palmer TM, Gadd ME (2005) Competition and compensation among cattle, zebras, and elephants in a semi-arid savanna in Laikipia, Kenya. Biological Conservation 122(2): 251-259. https://doi.org/10.1016/j.biocon.2004.08.007 